\title{
The interactions between Chinese local corn and WTI crude oil prices: an empirical analysis
}

\author{
Zhengwei Ma' ${ }^{1}$ Wenjia Hou ${ }^{1}$
}

Received: 28 October 2018 / Published online: 16 July 2019

(c) The Author(s) 2019

\begin{abstract}
This paper investigates the relationship between China's fuel ethanol promotion plan and food security based on the interactions between the crude oil market, the fuel ethanol market and the grain market. Based on the US West Texas Intermediate (WTI) crude oil spot price and Chinese corn prices from January 2008 to May 2018, this paper applies Granger causality testing and a generalized impulse response function to explore the relationship between world crude oil prices and Chinese corn prices. The results show that crude oil prices are not the Granger cause of China's corn prices, but changes in world crude oil prices will have a long-term positive impact on Chinese corn prices. Therefore, the Chinese government should pay attention to changes in crude oil prices when promoting fuel ethanol. Considering the conduction effect between fuel ethanol and the food market, the government should also take some measures to ensure food security.
\end{abstract}

Keywords WTI crude oil spot price $\cdot$ Chinese corn price $\cdot$ Granger causality test $\cdot$ Impulse response analysis

\section{Introduction}

As a new generation of clean energy that can effectively alleviate energy security problems and environmental pollution problems, fuel ethanol has been widely used in the USA, Brazil, and the European Union. With the rapid development of the fuel ethanol industry, a large number of agricultural products, like corn, have been used in the production of new biofuels. The influence of price volatility in the crude oil market is expanding to non-energy commodity markets ( $\mathrm{Ji}$ and Fan 2012). The energy characteristics of food prices are becoming more and more obvious. The prices of corn and other foods have been affected by factors such as supply, demand and cost, and have also suffered from energy prices and energy policies (Xu et al. 2017). The increase in ethanol use will strengthen and change the nature of links between agricultural and energy markets (Thompson et al. 2009). By 2020, global mandates on biofuels will significantly affect

\section{Edited by Xiu-Qin Zhu}

Wenjia Hou

cupwjhou@163.com

1 School of Business Administration, China University of Petroleum (Beijing), Changping, Beijing 102249, People's Republic of China the prices, production and trade of major feedstock crops such as corn (Ali et al. 2013). The correlation between food prices and energy prices was originally low, but the surge in oil prices has stimulated the development of bioenergy and the growing demand for energy crops such as corn has led to an increase in the correlation between energy prices and food prices (Jiang et al. 2015; Bobcock 2012).

As shown in Fig. 1, in 2007, world crude oil prices continued to rise. In order to increase profits, many countries turned a large number of bulk agricultural products, which were planned to be exported, into the production of biofuels. For example, 20\% of America's corn production, $65 \%$ of European Union's canola production and 35\% of Association of Southeast Asian Nations' palm oil were turned into the production of biofuels, which had led to a decline in global agricultural commodities supply and thus pushing up prices of agricultural products, triggering a global food crisis. Affected by the food crisis, the number of undernourished people in the world has been on the rise since 2014, reaching an estimated 821 million in 2017 (FAO 2018). Having enough food to meet their nutritional needs is the most basic of human needs (Yang 2017). How to properly develop fuel ethanol in the case that 821 million people are still in hunger, how to deal with the contradictory relationship between the development of fuel ethanol and other major concerns like an international energy crisis, environmental pollution 


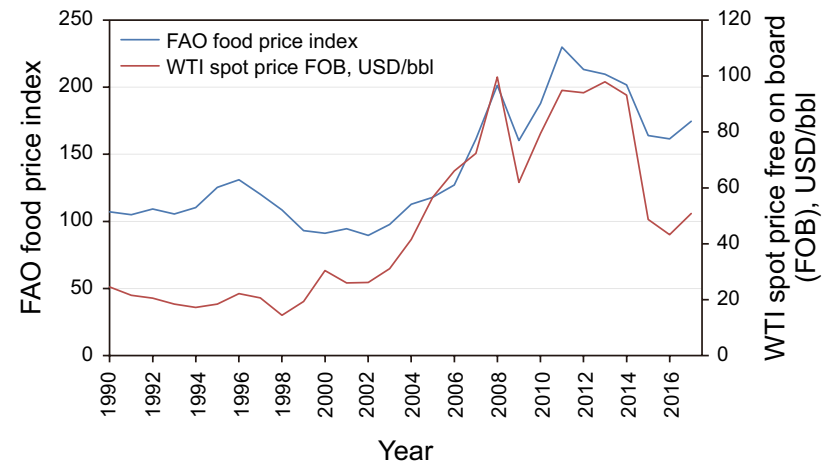

Fig. 1 Food and Agriculture Organization of the United Nations (FAO) Food Price Index (left) and spot price of WTI crude oil price (right) from 1990 to 2018

problems and food security issues have become a touchstone for that course.

Theoretically, the impact that crude oil prices has on biofuel raw materials such as corn and soybeans mainly include the following two aspects: First, crude oil is an important material input in the production, transportation and operation of crops such as corns and soybeans. Second, as a substitute for biofuels, the output and price of crude oil will affect the supply and demand of biofuel raw materials such as corn and soybean by affecting the supply and demand of biofuels, and further affect biofuels and the market price of raw materials. At the same time, the production and prices of biofuel raw materials such as corn and soybeans will also affect the production and demands for crude oil through the same path and further affect the prices of crude oil. Dillon and Barrett (2016) found that the immediate effects of correlated commodity price shocks on local food prices are driven more by transport costs than by grains themselves. The price transmission mechanism of crude oil and crops as biofuel feedstock is shown in Fig. 2 ( $\mathrm{Su}$ and Chen 2017).

In September 2017, the Chinese government issued the "Implementation Plan for Expanding Biofuel Ethanol Production and Promoting the Use of Ethyl Alcohol for Motor Vehicles," requiring the promotion of the use of automotive ethanol gasoline, i.e., gasoline with $10 \%$ denatured ethanol, throughout China, which was supposed to achieve full coverage by 2020. In 2016, China's gasoline consumption was 119.8 million tonnes (National Bureau of Statistics of China). Calculating at a $10 \%$ addition ratio, it would require
11.98 million tonnes of fuel ethanol. China's annual consumption of fuel ethanol in 2016 was only about 3 million tonnes (National Energy Administration of China), and the market potential is huge. Although the Chinese government has clearly stated that the main objective of the policy is to optimize the energy structure and regulate the grain market, fuel ethanol will be produced with low-quality grain and stale grain as raw materials, but precautions have to be taken to prevent necessary food for living from being over utilized, a potential risk of this policy. In 2010, the Chinese government's high subsidies to ethanol gasoline had driven alcohol factories to extensively rush for corn, thus disrupting the market of agricultural and associated products, indicating that in the face of a huge fuel ethanol market, Chinese companies are likely to snap up corn production. As a major food trade country in the world, China's corn imports in 2016 were 6.24 million tonnes. In 2017, China's corn imports were 8.58 million tonnes, up by $37.6 \%$ from 2016 (FAO, Food and Agriculture Organization of the United Nations). Some people are worried that the release of this policy is likely to further promote Chinese corn in usage and imports, which may even cause another sharp increase in global corn prices, once again triggering a food crisis. Therefore, studying the causal relationship between Chinese corn prices and international crude oil prices, accurate predictions of the Chinese corn market and the world corn market will be helpful in stabilizing food prices and ensuring world food security.

The purpose of this study was to use reliable data to assess the correlation between world crude oil prices and Chinese corn prices. This would help to analyze the possible impact of China's ethanol gasoline promotion plan to be implemented in 2020. The results of the study can help policy-makers in countries make effective decisions.

\section{Literature review}

Literature on the study of crude oil prices and food prices in the world can be divided into two parts by the research results. One part of the results indicated that crude oil prices have no effect on food prices. But the other part of the studies believes that crude oil prices have a certain impact on food prices. The literature that believes that there is an influential relationship between crude oil and food prices employed two

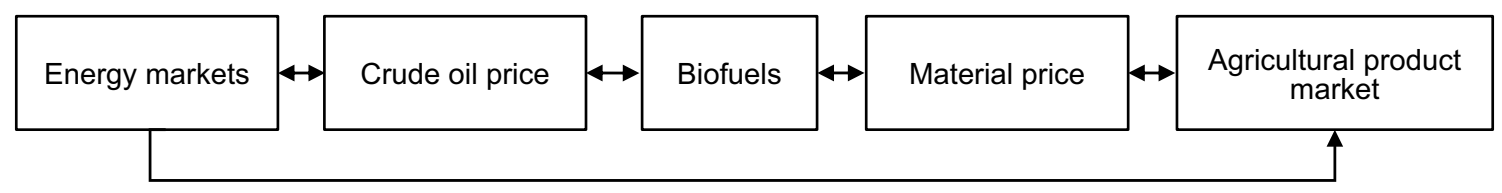

Fig. 2 Transmission mechanism of crude oil and crops 
types of methodology. Researchers who employed the first type of methodology studied the relationship between crude oil price changes and food price changes by studying the transmission mechanism between crude oil prices and food prices in a continuous period. The second type of methodology focuses on the relationship between crude oil prices and changes in food prices at different stages.

Some scholars found that crude oil prices have no effect on food prices. Ma et al. (2015) used the Granger causality test and a generalized impulse response to study the long-term and short-term effects that world crude oil prices and the RMB exchange rate against the US dollar have on the prices of agricultural products, such as corn and soybeans, and found that agricultural prices are neutral to the changes in oil prices in the long run. Zhang and Chen (2014) explored the effects of oil price shocks on China's fundamental industries, such as grains, and found that the grains indices did not significantly respond to the expected volatility in oil prices. Gardebroek and Hernandez (2013) examines volatility transmission in oil, ethanol and corn prices in the USA and did not find major cross-volatility effects between oil and corn markets. Baumeister and Kilian (2014) said there is no evidence that corn ethanol mandates have created a tight link between oil and agricultural markets. Fowowe (2016) studied the effects of oil prices on agricultural commodity prices in South Africa and found that agricultural commodity prices are neutral to global oil prices. Reboredo (2012) studied the common changes between world oil prices and world corn, soybean and wheat prices from January 1998 to April 2011 and found that there is no contagion between the crude oil and agricultural markets.

Some scholars found that crude oil prices have a certain impact on food prices by studying the relationship between crude oil prices and food prices in a continuous period. Ciaian and Kances (2011) studied interdependencies between the energy, bioenergy and food prices with direct and indirect input channels of price transmission and found that prices for crude oil and agricultural commodities are interdependent. Nazlioglu and Soytas (2012) applied panel cointegration and causality analysis to examine the dynamic relationship between world oil prices and world prices of agricultural commodities such as corn and wheat. Pal and Mitra (2017) evaluated the relationship between crude oil prices and the world food price and found that crude oil prices have long-term effects on the world food price index. Jadidzadeh and Serletis (2018) used a joint structural vector auto-regression (VAR) model to study the impact of crude oil supply and demand shocks on global corn prices and on US corn prices and found that close to $36 \%$ of the variation in the real price of US corn can be attributed to structural supply and demand shocks in the global crude oil market. Kyung and Jeong (2011) analyzed the impact of high international oil prices on the bioethanol and corn markets in the
USA by a structural vector auto-regression model (SVAR). Cha and Bea (2011) studied the impacts of high international oil prices on the bioethanol and corn markets in the USA and found that an increase in the oil price would increase corn prices in the short run. Koirala et al. (2015) used highfrequency data and newer methodology to study the dependence between US agricultural futures prices and energy futures prices and found that the two are highly correlated, and the rise in energy prices will lead to an increase in the prices of agricultural products. Alghalith (2010) examined the impact of Trinidad and Tobago oil price uncertainty on food prices by applying statistical methods and found that higher oil price volatility and reduction in oil supply led to higher food prices. In addition, the full sample rolling method is gradually applied to the study of crude oil prices and food prices. Peri and Baldi (2012) studied the free-onboard (FOB) price of diesel and rapeseed oil in the Nordic market, applying the rolling cointegration analysis method to study the correlation between the price of diesel fuel and the price of rapeseed oil caused by the impact of biofuel policy. Nicola et al. (2016), based on rolling regression analysis, proved that the development of biofuel technology since 2007 caused the transmission effect of crude oil prices on corn and soybean prices to be further strengthened.

Some scholars focus on the relationship between crude oil prices and changes in food prices at different stages and have discovered the transmission effects between crude oil prices and food prices. Du et al. (2011) studied the relationship between the weekly average settlement prices of crude oil futures, corn futures and wheat futures on the New York Mercantile Exchange from November 1998 to January 2009 and found that the crude oil, corn and wheat markets were related volatility occurred after the fall of 2006. Avalos (2014) analyzed the time series characteristics of oil, corn and soybean prices in different periods in the USA with 2006 as a breakpoint and found that the market's use of corn ultimately depends on the price of petroleum relative to ethanol, so oil prices have become a relevant factor in the global corn market. Lucotte (2016) also used 2006 as a breakpoint to study the relationship between crude oil price and food price in a period of pre-commodity-boom (1990M1-2006M12) and a post-boom period (2007M-2012M5) using a VAR model. Nazlioglu et al. (2013) studied the volatility transfer between world crude oil prices and the prices of specific agricultural products such as corn in the two periods before and after the 2006 food crisis and found that the fluctuations in the oil market began to spread to the agricultural market after the food crisis. Wang et al. (2014) subdivided the oil shock into supply shocks, demand shocks and other oil-specific shocks, explaining the relationship between oil prices and agricultural product prices before and after the 2006-2008 food crisis. Chiu et al. (2016) broke the world price data of crude oil, corn and ethanol from January 1986 
to August 2015 into three cycles and studied the long-term relationship between the three variables by a vector autoregressive model and a vector error correction model. Chen et al. (2010)analyzed the relationship between world crude oil prices and world corn, soybean and wheat prices from 1997 to 2008 with the breakpoint of Week 49, 1985 and Week 3, 2005 and believed that the development of high oil prices and biofuels would lead poor countries to food losses.

Since the Chinese corn market has not experienced excessive fluctuations, the research in this study will be based on the relationship between crude oil prices and Chinese corn prices in a continuous period. The purpose of this paper is to examine whether there is an interaction between crude oil prices and Chinese corn prices, so the study will be conducted with the Granger causality test. This paper also uses generalized impulse response analysis to further analyze the long-term causal relationship between crude oil prices and Chinese corn wholesale prices.

\section{Empirical methods}

\subsection{Unit root test}

The use of least squares for non-stationary time series estimation results in a biased estimate of the result. Therefore, in general, the first step is the stationarity (unit root) test of the time series to determine the order of integration of all selected variables (Dong et al. 2018). If the time series are both horizontally stable sequences or non-single-order single integers, subsequent studies will use the VAR model. If the variables are in the same order, the subsequent existence of the cointegrating equation will be further tested.

\subsection{Cointegration test}

It is very important to test the cointegration relationship between variables and to choose model variables from the cointegration relationship between variables. The two-variable Engle-Granger test and the multivariate Johansen test are commonly used in econometrics.

\subsubsection{EG-integration test}

The Engle-Granger test (EG-integration test), was developed by Engel and Granger in a two-step test in 1987 to test whether there exists cointegration relationship between $Y_{t}$ and $X_{t}$. The method comprises two steps.

Step 1: Estimate the equation using the ordinary least square (OLS) method

$Y_{t}=\alpha_{0}+\alpha_{1} X_{t}+\mu_{t}$

After calculating the imbalance error, we get
$\widehat{Y}_{t}=\widehat{\alpha}_{0}+\widehat{\alpha}_{1} X_{t}$

$e_{t}=Y_{t}-\hat{Y}_{t}$

which is called cointegrating.

Step 2: Test the stability of $e_{t}$ by using the DF test method or the Augmented Dickey-Fuller (ADF) test method. If the sequence $I(0)$ is stationary, the variables $Y_{t}$ and $X_{t}$ are considered to be co-integral to $(1,1)$. Otherwise, the authors say there are no covariance relationship between the variables $Y_{t}$ and $X_{t}$.

\subsubsection{Johansen cointegration test}

For the test of multivariate cointegration relations, the Johansen cointegration test based on the vector autoregressive method by Johansen and Juselius (1990) is used.

First, the authors need to build a VAR(q) model.

$y_{t}=\emptyset_{1} y_{t-1}+\cdots+\emptyset_{p} y_{t-p}+H x_{t}+\epsilon_{t}, \quad t=1,2, \ldots, T$

Each of these components is a non-residual sequence and is a first-order integral $x_{t}$ is a fixed exogenous vector, representing a constant term, a trend term, and so on. $\epsilon_{t}$ is the $\mathrm{k}$-dimensional perturbation vector.

Doing the calculus of finite differences and the authors will get

$\Delta y_{t}=\prod y_{t-1}+\prod_{i=1}^{p-1} \tau_{i} \Delta y_{t-i}+H x_{t}+\epsilon_{t}$

$\prod=\sum_{i=1}^{p} \emptyset_{i}-1$

$\tau_{i}=-\sum_{j=i+1}^{p} \emptyset_{j}$

$I(0)$ can be obtained by performing a finite difference transform of the $I(1)$ process. Therefore, when $\prod y_{t-1}$ is a vector of $I(0), \Delta y_{t}$ is stationary.

\subsection{Granger causality test}

The cointegration test can only explain whether there is a long-term equilibrium relationship between variables, but if the authors want to examine whether there is a long-term causal relationship between variables, further research is needed. The Granger causality test is used to test the causal relationship between variables. The concept is first proposed by Granger (1969): assuming $X$ is the cause of $Y$, but $Y$ is not 
the cause of $X$, then the past values of $X$ should be able to help predict future values of $Y$, but the past value of $Y$ cannot predict the future value of $X$.

The hypothesis test model for the Granger causality test is

$Y_{t}=\gamma+\sum_{i=1}^{p} \alpha_{i} Y_{t-i}+\sum_{j}^{q} \beta_{j} \Delta X_{t-j}+\epsilon_{t}$

For the test of whether $X$ is causative to $Y$, the null hypothesis is

$H_{0}: \beta_{1}=\beta_{2}=\cdots=\beta_{q}=0$

The number of constraints is $J=q$.

If the null hypothesis is true, the authors can get:

$Y_{t}=\gamma+\sum_{i=1}^{p} \alpha_{i} Y_{t-i}+\epsilon_{t}$

Define the F statistical quantity as

$F=\frac{\left(\mathrm{SSE}_{1}-\mathrm{SSE}_{0}\right) / q}{\mathrm{SSE}_{0} /(T-q-p-1)}$

In this formula, $p$ and $q$ are the lag intervals of the endogenous variables $Y$ and $X$, respectively, which was determined by the Akaike information criterion (AIC). Only when the F statistic is greater than the critical value can the original hypothesis be rejected.

\section{Data process}

The data used in the empirical analysis are weekly data on world crude oil prices (CO), RMB exchange rate (ER), and Chinese corn prices (C) for the decade from January 2008 to May 2018. Crude oil prices are expressed as the US West Texas Intermediate (WTI) weekly prices, available at the US
Energy Information Administration (EIA). Exchange rates are expressed as the amount of RMB required to obtain a unit of US dollars, available at the Central Bank of China. Chinese corn prices are expressed in terms of the average wholesale prices of domestic corn in China, available in the Ministry of Agriculture of China.

\subsection{International crude oil price}

International crude oil price data is derived from the freeon-board (FOB) crude oil spot price published by the US Energy Information Administration (EIA) in USD/bbl (US dollars per barrel), expressed as CO. Modern international oil prices include the US West Texas Intermediate (WTI) price, the European Brent price and the Organization of the Petroleum Exporting Countries (OPEC) package price. This paper uses the WTI crude oil spot price weekly data to measure the impact of fluctuations in international crude oil prices. As can be seen from Fig. 3, the crude oil price dropped rapidly after the third quarter of 2008 , and the price bottomed out at the end of 2008 . The international crude oil prices rebounded again in the first half of 2009, and it is in a state of rising volatility, but the price level has not exceeded that of mid-2008. The price level of the international crude oil in the second half of 2014 fell again. In February 2016, the international crude oil price fell below the lowest level in 2008 and began to fluctuate.

\subsection{Chinese corn wholesale average price}

The prices of corn came from Wind database Chinese corn wholesale average price, with a unit of $\mathrm{CNY} / \mathrm{kg}$, expressed as C. For the sake of comparison, the average prices of Chinese corn wholesale in the original data were converted to USD/tonne according to the intermediate prices of USD/ CNY published by the People's Bank of China during data analysis. Figure 4 shows the average prices of Chinese corn
Fig. 3 WTI crude oil spot price in 2008-2018

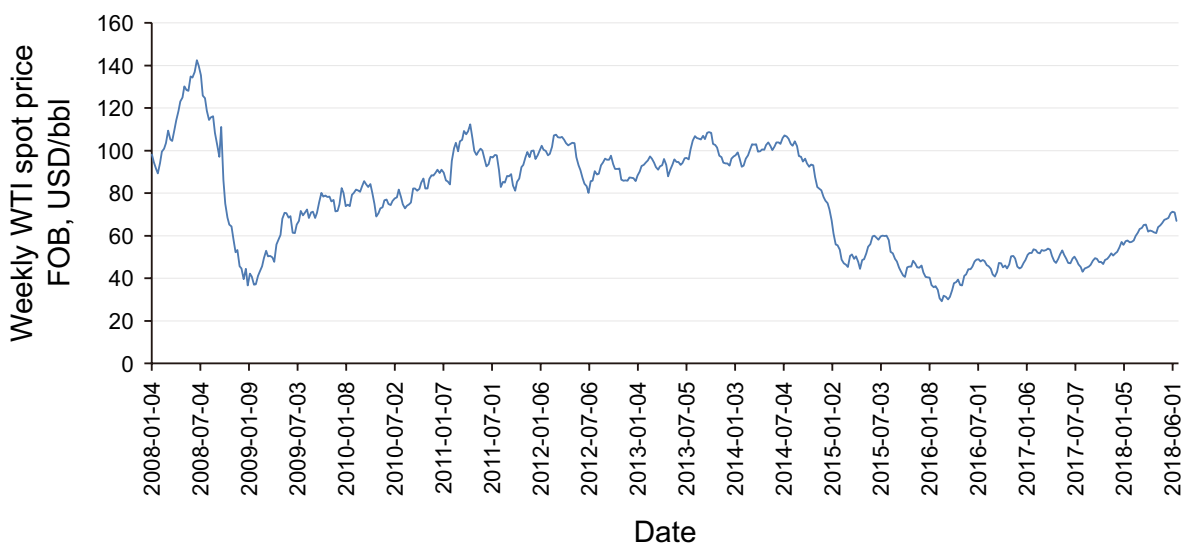

Date Source: U.S. Energy Information Administration (EIA) 
Fig. 4 Average price of Chinese corn wholesale in 2008-2018

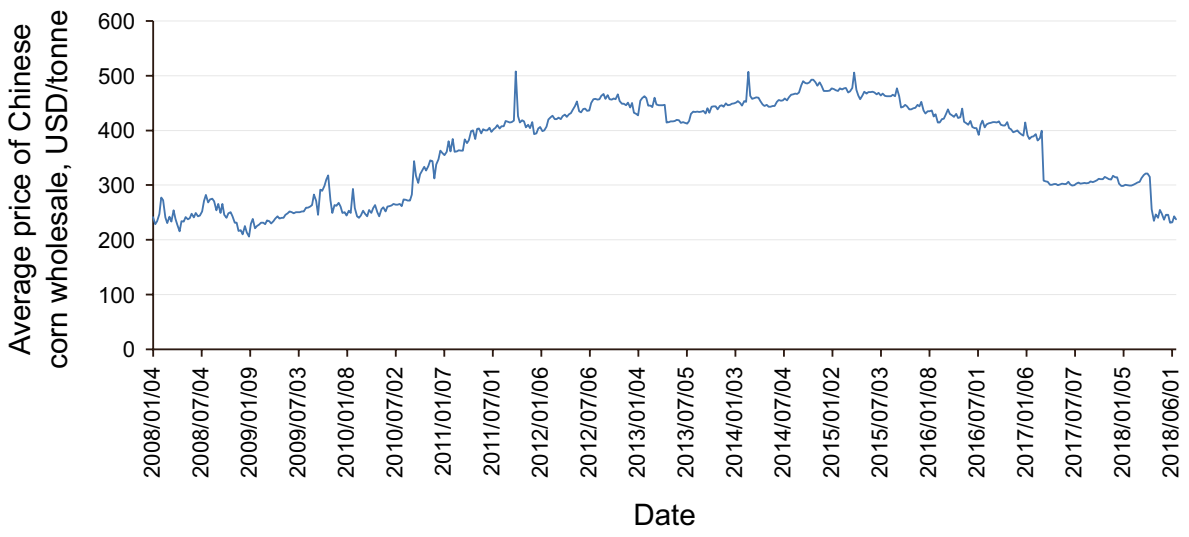

Date Source: Wind Economic Database

wholesale from 2008 to 2018 after the unit conversion. As can be seen from the figure, Chinese corn prices have generally risen and then declined since 2008 .

\subsection{Exchange rate}

The exchange rate is derived from the median price of the CNY/USD exchange rate in the People's Bank of China, expressed as ER. In July 2005, China began to implement exchange rate reform and changed from a fixed exchange rate system to a government intervened floating exchange rate system which is based on market supply and demand, with reference to a basket of currencies. Figure 5 shows the median price chart of the CNY/USD exchange rate for 2008-2018. It can be seen from the figure that in 2008-2015, the US dollar was basically depreciated and began to gradually recover from the beginning of 2016 .

\subsection{Descriptive statistics}

As can be seen from Table 1, WTI international crude oil prices from 2008 to 2018 reached their highest at 142.52
$\mathrm{USD} / \mathrm{bbl}$, the lowest at $29.19 \mathrm{USD} / \mathrm{bbl}$, and the average price was $76.25 \mathrm{USD} / \mathrm{bbl}$. The price distribution was obviously right-biased and the kurtosis is lower than the third kurtosis of normal distribution. The average wholesale price of Chinese corn from 2008 to 2018 reached the highest price at 508.27 USD/tonne, the lowest price at 206.19 USD/tonne, and the average price at $366.56 \mathrm{USD} /$ tonne. The price distribution is obviously left-biased, and the kurtosis is lower than the normal distribution kurtosis 3 . The exchange rate from 2008 to 2018 reached its highest at 7.28 USD/CNY and its lowest at $6.10 \mathrm{USD} / \mathrm{CNY}$. The US dollar price distribution is right-biased, and the kurtosis is lower than the normal distribution kurtosis 3 .

\section{Empirical findings}

\subsection{Unit root test}

In this paper, the authors used the Augmented Dickey-Fuller (abbreviated as ADF) test and the Phillips-Perron (abbreviated as PP) test to verify the stability
Fig. 5 RMB exchange rate in 2008-2018

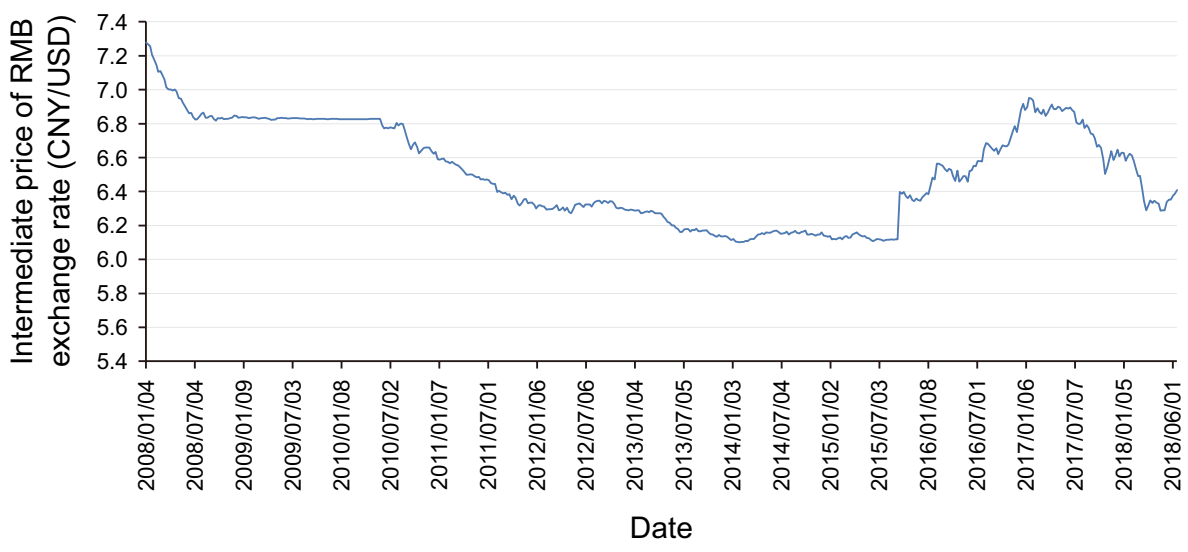

Date Source: The People's Bank of China 
Table 1 Descriptive statistics

\begin{tabular}{lcccc}
\hline & $\begin{array}{l}\text { WTI spot price } \\
\text { FOB, USD/bbl }\end{array}$ & $\begin{array}{l}\text { Weekly Europe, } \\
\text { USD/bbl }\end{array}$ & $\begin{array}{l}\text { Chinese corn wholesale } \\
\text { average price, USD/tonne }\end{array}$ & $\begin{array}{l}\text { Exchange } \\
\text { rate, CNY/ } \\
\text { USD }\end{array}$ \\
\hline Standard error & 1.09 & 1.25 & 3.88 & 0.01 \\
Standard deviation & 24.45 & 27.94 & 87.07 & 0.29 \\
Kurtosis & -0.97 & -1.40 & -1.46 & -1.20 \\
Skewness & 0.05 & -0.02 & -0.32 & 0.17 \\
Min & 29.19 & 27.76 & 206.19 & 6.10 \\
Max & 142.52 & 141.07 & 508.27 & 7.28 \\
Observations & 503.00 & 503.00 & 503.00 & \\
\hline
\end{tabular}

Table 2 Results for the unit root tests of WTI crude oil price

\begin{tabular}{llllll}
\hline & ADF & & & PP & \\
\cline { 2 - 3 } & Statistics & Prob. & & Statistics & Prob. \\
\hline Levels & & & & \\
Intercept & -1.770074 & 0.3954 & -2.111392 & 0.2403 \\
Intercept and trend & -1.981554 & 0.6095 & -2.388914 & 0.3849 \\
First-difference & & & & \\
Intercept & -18.57250 & 0.0000 & -19.33467 & 0.0000 \\
Intercept and trend & -18.55411 & 0.0000 & -19.31842 & 0.0000 \\
\hline
\end{tabular}

Table 3 Results for the unit root tests of Chinese corn wholesale average price

\begin{tabular}{llllll}
\hline & ADF & & & PP & \\
\cline { 2 - 3 } & Statistics & Prob. & & Statistics & Prob. \\
\hline Levels & & & & \\
Intercept & -1.129263 & 0.7056 & -1.140652 & 0.7009 \\
Intercept and trend & -0.068393 & 0.9953 & -0.053551 & 0.9955 \\
First-difference & & & & \\
Intercept & -20.61183 & 0.0000 & -29.50454 & 0.0000 \\
Intercept and trend & -20.85105 & 0.0000 & -30.81901 & 0.0000 \\
\hline
\end{tabular}

of each variable. If the horizontal sequence is not stationary, the authors will continue to test the stability of the first-order lag of each variable. The results of the stationarity test are shown in Tables 2 and 3 .

It can be seen from Tables 2 and 3 that the time series of WTI international crude oil price and Chinese corn wholesale average price are non-stationary sequences. After the first-order difference, it is stable at 5\% significance level, so the logarithm of the average wholesale price of Chinese corn (abbreviated as LC) and the logarithm of international crude oil price (abbreviated as
Table 4 Johansen cointegration test

\begin{tabular}{lllll}
\hline $\begin{array}{l}\text { Hypoth- } \\
\text { esized no. of } \\
\text { CE(s) }\end{array}$ & Eigenvalue & Trace statistic & $\begin{array}{l}0.05 \text { critical } \\
\text { value }\end{array}$ & Prob.* $^{*}$ \\
\hline None & 0.015744 & 8.878187 & 15.49471 & 0.3768 \\
At most 1 & 0.001956 & 0.975275 & 3.841466 & 0.3234 \\
\hline
\end{tabular}

Trace test indicates no cointegration at the 0.05 level

*MacKinnon-Haug-Michelis (1999) $p$ values

LCO) are integrated of order one I(1), which means the authors can build a cointegration model.

\subsection{Johanson cointegration test}

Before the Johanson cointegration test and the vector error correction model test, the lagged rank of the model should be determined first. The lagged period of the cointegration test model is the lagged period of the first-order difference variables of the unconstrained VAR model. Through experiment, the authors confirmed that the excellent lagged period of the unconstrained VAR model is 4 , so they determined the lagged period of the cointegration test to be 3 . Table 4 shows the results of the Johanson cointegration test between 2008 and 2018, with the assumption that there is no cointegration relationship between variables. The maximum eigenvalue test indicates that there is no cointegration relationship between variables between 2008 and 2018 .

\subsection{Unit root map}

In addition to testing the cointegration relationship, the validity of the data should also be verified. The data validity check is performed by the AR root map. The result is shown in Fig. 6.

The dots in Fig. 6 indicate the position of the unit root. Since they were all described in the unit circle, i.e., no root lies outside the unit circle, the authors can assert that the 


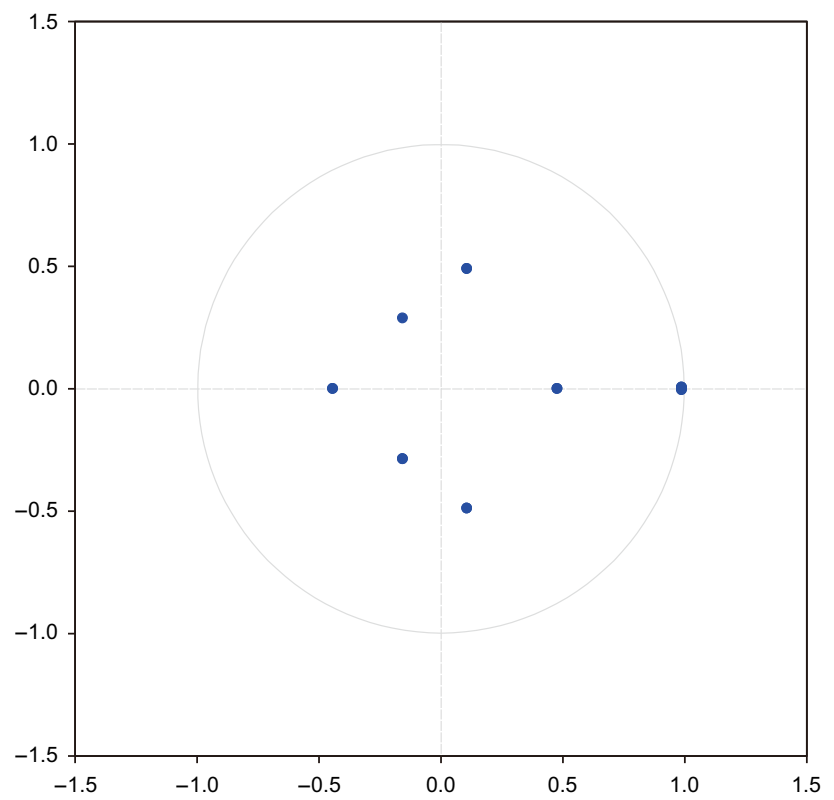

Fig. 6 Inverse roots of AR characteristic polynomial

Table 5 Granger causality test

\begin{tabular}{lll}
\hline & LC & LCO \\
\hline LC & & 6.759581 \\
LCO & 3.095326 & \\
\hline
\end{tabular}

VAR(4) model is stationary and does not affect the impulse response function. The Granger causality test was then carried out.

\subsection{Granger causality test}

The Granger causality test was used to analyze the causal relationship between the international crude oil prices, the RMB exchange rate and the average wholesale prices of

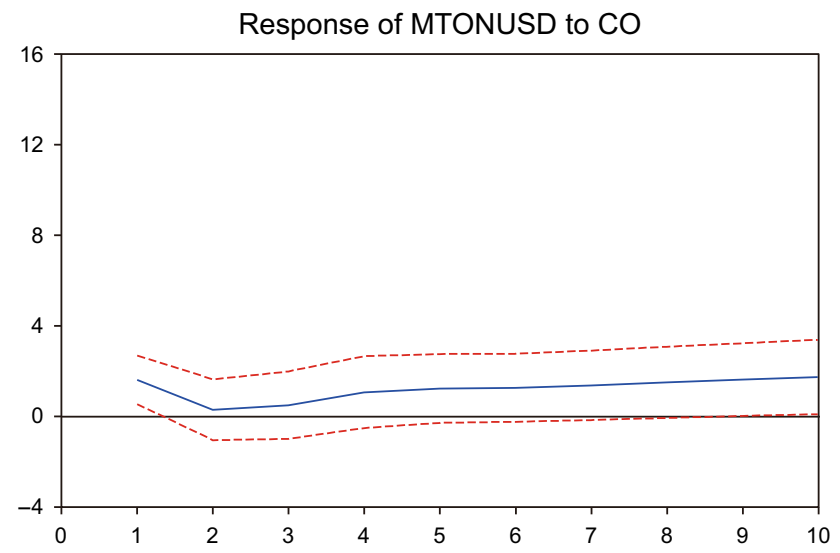

corn in China. The test results of each endogenous variable (specified variable) relative to the Granger causality test statistic of other endogenous variables in the model are shown in Table 5. The logarithm of the average wholesale price of Chinese corn is denoted as LC, and the logarithm of international crude oil price denoted as LCO as in Table 5.

The long-term causality test shows that the international crude oil price is not the Granger reason for the average wholesale price of corn in China, and the average wholesale price of corn in China is not the Granger reason for the international crude oil price. The reason for this result may be that China's agricultural policy and refined oil pricing policy have weakened the impact of international crude oil prices on China's wholesale price of corn and may also be related to the use of China's fuel ethanol during 2008-2018.

\subsection{Generalized impulse response analysis}

Since the long-term Granger causality analysis failed to show the relationship between crude oil prices and Chinese corn wholesale prices, it was further analyzed by generalized impulse response analysis. Figure 7 shows the degree of deviation of different corn prices given a single standard deviation shock. The CO stands for crude oil and the MTONUSD stands for corn in USD/tonne. As can be seen from Fig. 7, when the international crude oil price in the current period gives the corn industry a positive impact, the average price of Chinese corn wholesale will decline in the first two periods, starting from the second period and beginning to grow steadily since then. When the China's corn price in the current period gives the world crude oil market a positive impact, international crude oil prices are basically unaffected.

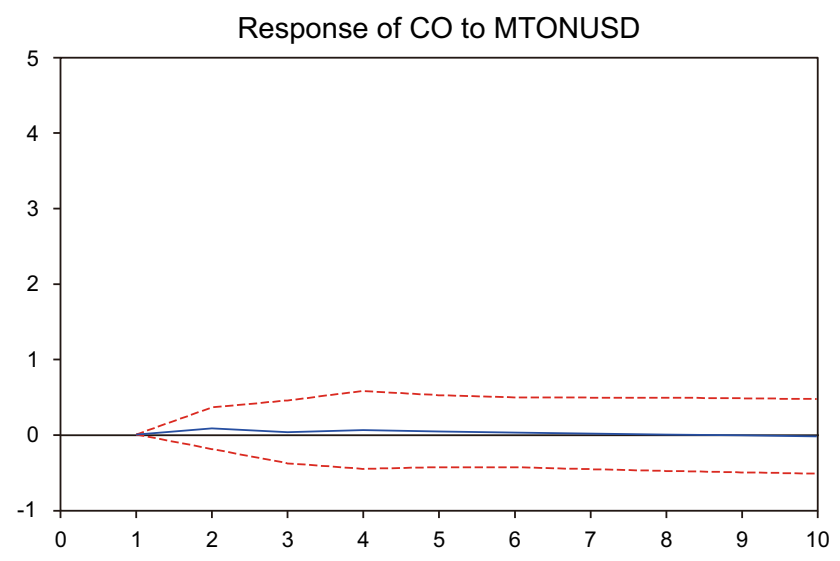

Fig. 7 Response to one-standard innovations 


\section{Conclusion and suggestion}

This paper analyzed the weekly data of WTI international crude oil prices, Chinese corn wholesale average prices and the RMB exchange rate against the US dollar from January 2008 to May 2018, and studied the relationship between the average price of Chinese corn wholesale and WTI international crude oil price. Through the Granger causality test and generalized impulse response analysis of China's average wholesale prices of corn and WTI international crude oil prices, the authors are convinced that WTI international crude oil prices are not the Granger reason for the change of average wholesale prices of corn in China, yet changes in WTI international crude oil prices will have a long-term positive impact on the average wholesale prices of corn in China; at the same time, the average wholesale prices of corn in China are not the Granger cause of WTI international crude oil price, and the change in the average wholesale prices of corn in China will not affect WTI international crude oil.

As a major energy consumer and importer in the world, China's energy policy changes are likely to have an impact on the world's energy market. But this study shows that because China's corn imports account for only a small proportion of the world's corn trade, changes in China's corn prices will not have a major impact on the world food market. Since China's fuel ethanol is based on low-quality grain and stale grain, there is no need to worry too much about the impact of China's corn ethanol promotion plan on world food security issues.

China's national promotion of the use of fuel ethanol for vehicles will greatly increase the demand for fuel ethanol in China. It is recommended that Chinese companies expand their fuel ethanol production capacity to make up for market shortfalls.

Guo et al. (2011) have found that the development of corn bioethanol will affect the demand for corn. Huang et al. (2009) have also found that the development of fuel ethanol will significantly increase the price of agricultural products for energy crops and have a negative impact on food security. In order to ensure China's food security, the Chinese government should strengthen the regulation of the food market and the fuel ethanol market while controlling the production and consumption of fuel ethanol. The Chinese government should strengthen supervision of fuel ethanol production. For example, the government can grant cash subsidies or income tax deductions to factories which produce fuel ethanol based on regulations, and penalize factories which use grain corn as raw materials to control the source of fuel ethanol production raw materials, and ensure that the food flow meets the government's regulations. China's fuel ethanol market has great potential. As the main raw material for fuel ethanol production in China is corn, an increase in demand for fuel ethanol may lead to an increase in demand for corn and may drive a sharp rise in corn prices. So the Chinese government should pay close attention to the changes in China's corn prices. At the same time, considering the relationship between crude oil prices and corn prices, the Chinese government needs to pay attention to changes in international crude oil prices, too.

China's fuel ethanol market is still in its infancy. In the short term, the development of fuel ethanol needs to rely on government policy support. It requires the government to provide long-term and stable policy support for ethanol gasoline. In the long run, China's fuel ethanol development also needs the support of technology. Therefore, while promoting the development of the fuel ethanol market, the government should also pay attention to the support of fuel ethanol production technology, such as setting up special funds to provide financial support for fuel ethanol projects, and promote research into fuel ethanol production technology to reduce the cost of fuel ethanol production and to improve competitiveness through technological progress.

Acknowledgements The authors would like to express their deepest appreciation to all the individuals who have helped them in the completion of the study. The project was sponsored by MOE Project of Humanities and Social Sciences (Project No. 17YJC790107). The project was sponsored by the National Social Science Foundation of China (Project No. 18BJY251)

\section{Compliance with ethical standards}

Conflict of interest The authors declare that they have no conflict of interest.

Open Access This article is distributed under the terms of the Creative Commons Attribution 4.0 International License (http://creativeco mmons.org/licenses/by/4.0/), which permits unrestricted use, distribution, and reproduction in any medium, provided you give appropriate credit to the original author(s) and the source, provide a link to the Creative Commons license, and indicate if changes were made.

\section{References}

Alghalith M. The interaction between food prices and oil prices. Energy Econ. 2010;32(6):1520-2. https://doi.org/10.1016/j.eneco .2010.08.012.

Ali T, Huang J, Yang J. Impact assessment of global and national biofuels developments on agriculture in Pakistan. Appl Energy. 2013;104:466-74. https://doi.org/10.1016/j.apene rgy.2012.11.047.

Avalos F. Do oil prices drive food prices? The tale of a structural break. J Int Money Finance. 2014;42:253-71. https://doi.org/10.1016/j. jimonfin.2013.08.014. 
Baumeister C, Kilian L. Do oil price increases cause higher food prices? Econ Policy. 2014;29:691-747. https://doi.org/10.1111/14680327.12039.

Bobcock BA. The impact of US biofuel policies on agricultural price levels and volatility. China Agric Econ Rev. 2012;4(4):407-26. https://doi.org/10.1108/17561371211284786.

Cha KS, Bae JH. Dynamic impacts of high oil prices on the bioethanol and feedstock markets. Energy Policy. 2011;39(2):753-60. https ://doi.org/10.1016/j.enpol.2010.10.049.

Chen ST, Kuo HI, Chen CC. Modeling the relationship between the oil price and global food prices. Appl Energy. 2010;87(8):2517-25. https://doi.org/10.1016/j.apenergy.2010.02.020.

Chiu FP, Hsu CS, Ho A, Chen CC. Modeling the price relationships between crude oil, energy crops and biofuels. Energy. 2016;109:845-57. https://doi.org/10.1016/j.energy.2016.05.016.

Ciaian P, Kances A. Interdependencies in the energy-bioenergy-food price systems: a cointegration analysis. Resour Energy Econ. 2011;33:326-48. https://doi.org/10.1016/j.reseneeco.2010.07.004.

Dillon BM, Barrett CB. Global oil prices and local food prices: evidence from east Africa. Am J Agric Econ. 2016;98(1):154-71. https://doi.org/10.1093/ajae/aav040.

Dong KY, Sun RJ, Dong XC. $\mathrm{CO}_{2}$ emissions, natural gas and renewables, economic growth: assessing the evidence from China. Sci Total Environ. 2018;640-641:293-302. https://doi.org/10.1016/j. scitotenv.2018.05.322.

Du X, Yu CL, Hayes DJ. Speculation and volatility spillover in the crude oil and agricultural commodity markets: a Bayesian analysis. Energy Econ. 2011;33(3):497-503. https://doi.org/10.1016/j. eneco.2010.12.015.

FAO (Food and Agriculture Organization of the United Nations) (2018) The state of food security and nutrition in the world. Rome: FAO. http://www.fao.org/state-of-food-security-nutrition/en/.

Fowowe B. Do oil prices drive agricultural commodity prices? evidence from South Africa. Energy. 2016;104:149-57. https://doi. org/10.1016/j.energy.2016.03.101

Gardebroek C, Hernandez MA. Do energy prices stimulate food price volatility? Examining volatility transmission between US oil, ethanol and corn markets. Energy Econ. 2013;40:119-29. https ://doi.org/10.1016/j.eneco.2013.06.013.

Granger CWJ. Investigating causal relations by econometric models and cross-spectral methods. Econometrica. 1969;37(3):424-38.

Guo LX, Huang CX, Peng KL. Does development of bio-energy really affect the "food"? - based on the development of Chinese corn bio-ethanol. Forum Sci Technol China. 2011;9:139-45. https:// doi.org/10.13580/j.cnki.fstc.2011.09.024 (in Chinese).

Huang JK, Qiu HG, Keyzer M, Meng E, Veen MV. Impacts of bioethanol development on China's regional agricultural development. China Econ Q. 2009;8(2):727-42. https://doi.org/10.13821/j.cnki. ceq.2009.02.002 (in Chinese).

Jadidzadeh A, Serletis A. The global crude oil market and biofuel agricultural commodity prices. J Econ Asymmetries. 2018. https://doi. org/10.1016/j.jeca.2018.e00094.

Ji Q, Fan Y. How does oil price volatility affect non-energy commodity markets? Appl Energy. 2012;89(1):273-89. https://doi. org/10.1016/j.apenergy.2011.07.038.

Jiang JZ, Marsh TL, Tozer PR. Policy induced price volatility transmission: linking the U.S. crude oil, corn and plastics markets. Energy Econ. 2015;52:217-27. https://doi.org/10.1016/j.eneco .2015.10.008.
Johansen S, Juselius K. Maximum likelihood estimation and inference on cointegration with applications to the demand for money. Oxf Bull Econ Stat. 1990;52:169-210.

Koirala KH, Mishra AK, D’Antoni JM, Mehlhorn JE. Energy prices and agricultural commodity prices: testing correlation using copulas method. Energy. 2015;81:430-6. https://doi.org/10.1016/j. energy.2014.12.055.

Kyung SC, Jeong HB. Dynamic impacts of high oil prices on the bioethanol and feedstock markets. Energy Policy. 2011;39:75360. https://doi.org/10.1016/j.enpol.2010.10.049.

Lucotte Y. Co-movements between crude oil and food prices: a postcommodity boom perspective. Econ Lett. 2016;147:142-7. https ://doi.org/10.1016/j.econlet.2016.08.032.

Ma ZW, Xu R, Dong XC. World oil prices and agricultural commodity prices: the evidence from China. Agric Econ. 2015;12:564-76. https://doi.org/10.17221/6/2015-AGRICECON.

Nazlioglu S, Erdem C, Soytas U. Volatility spillover between oil and agricultural commodity markets. Energy Econ. 2013;36:658-65. https://doi.org/10.1016/j.eneco.2012.11.009.

Nazlioglu S, Soytas U. Oil price, agricultural commodity prices, and the dollar: a panel cointegration and causality analysis. Energy Econ. 2012;34(4):1098-104. https://doi.org/10.1016/j.eneco .2011.09.008

Nicola FD, Pace PD, Hernandez MA. Co-movement of major energy, agricultural, and food commodity price returns: a timeseries assessment. Energy Econ. 2016;57:28-41. https://doi. org/10.1016/j.eneco.2016.04.012.

Pal D, Mitra SK. Time-frequency contained co-movement of crude oil and world food prices: a wavelet-based analysis. Energy Econ. 2017;62:230-9. https://doi.org/10.1016/j.eneco.2016.12.020.

Peri M, Baldi L. The effect of biofuel policies on feedstock market: empirical evidence for rapeseed oil prices in EU. Resour Energy Econ. 2012;35(1):18-37. https://doi.org/10.1016/j.resen eeco.2012.11.002.

Reboredo JC. Do food and oil prices co-move? Energy Policy. 2012;49:456-67. https://doi.org/10.1016/j.enpol.2012.06.035.

$\mathrm{Su} \mathrm{Z}$, Chen Z. The research on relationship between the corn price and the oil price in China based on the transmission mechanism. J Ocean Univ China (Soc Sci). 2017;01:70-6. https://doi. org/10.16497/j.cnki.1672-335x.2017.01.010 (in Chinese).

Thompson W, Meyer S, Westhoff P. How does petroleum price and corn yield volatility affect ethanol markets with and without an ethanol use mandate? Energy Policy. 2009;37(2):745-9. https:// doi.org/10.1016/j.enpol.2008.08.035.

Wang Y, Wu C, Yang L. Oil price shocks and agricultural commodity prices. Energy Econ. 2014;44:22-35. https://doi.org/10.1016/j. eneco.2014.03.016.

Xu YY, Yan ZR, Wang CM, Zhang SY. Research on the transmission effects of crude oil price on grain price by the rolling cointegration model. Res Agric Mod. 2017;38(4):605-13. https://doi. org/10.13872/j.1000-0275.2017.0044 (in Chinese).

Yang X. The development of world food trade after the crisis and its impact on China's food security. Inner Mong Soc Sci. 2017;38(3):120-4. https://doi.org/10.14137/j.cnki.issn10035281.2017.03.019 (in Chinese).

Zhang CG, Chen XQ. The impact of global oil price shocks on China's bulk commodity markets and fundamental industries. Energy Policy. 2014;66:32-41. https://doi.org/10.1016/j.enpol.2013.09.067. 